BISMA

(Bisnis dan Manajemen)
Volume 13, Issue 1, 2020, 14-25

ISSN 2549-7790 (Online)

DOI: 10.26740/bisma.v13n1.p14-25

https://journal.unesa.ac.id/index.php/bisma/index

\title{
Linking work environment to employee performance: the mediating role of work discipline
}

\author{
Achmad Sani Supriyanto $^{1 *}$, Vivin Maharani Ekowati ${ }^{2}$, Hilda Vironika ${ }^{3}$ \\ ${ }^{1,2,3}$ State Islamic University of Maulana Malik Ibrahim, Indonesia
}

\begin{abstract}
This study aims to examine the influence of the work environment on employee performance mediated by work discipline. It is quantitative research with questionnaires as the data collection method. Data were analyzed by using Path Analysis. The populations are all of the full-time employees, and seventyeight respondents of them were selected by saturated sampling method. The study shows that the work environment affects employee performance, and work discipline mediates the effect of the work environment on employee performance.
\end{abstract}

Keywords: employee performance; work environment; work discipline

Received: February 14, 2020; Accepted: July 21, 2020; Published: October 31, 2020

*Corresponding author

Email: achmad_sani72@yahoo.com

To cite this document:

Supriyanto, A. S., Ekowati, V. M., \& Vironika, H. (2020). Linking work environment to employee performance: the mediating role of work discipline. BISMA (Bisnis dan Manajemen), 13(1), 14-25. https://doi.org/10.26740/bisma.v13n1.p14-25

\section{INTRODUCTION}

Human resource is the most important elements of an organization. An organization will never work without a human resource role because they are the driving force and the leading player of the organization (Sani \& Ekowati, 2019). Therefore, it is prominent that an organization provides a positive direction to achieve the goals. Understanding the importance of human resources in the global era is one of the efforts to improve their quality. It is expected that employes can improve their performance through quality improvement. Employee performance has an impact on employee attitudes when accepting the work and everything within the work environment (Sunyoto, 2013).

Employee performance is an action of the employees upon performing the job given. Performance is a result of the relationship between effort, ability, and perceptual tasks charged (Timpe, 2002). Every company must put a high expectation towards the employees that they can excel in their performance because excellent performance means an optimal contribution to the company (Wijaya \& Susanti, 2017). One of the aspects that play an essential role in the 
Supriyanto, A. S., Ekowati, V. M., \& Vironika, H. Linking work environment to employee performance: the mediating role of work discipline company and affect the performance of employees is the work environment (Kuswandi, 2004). A good work environment can create an excellent performance of employees as expected by the company. On the other hand, an uncomfortable work environment can degrade their performance (Putri et al., 2019).

Sedarmayanti (2009) defined that work environment is all circumstances around the workplace that will affect the employees, both directly and indirectly. Pawirosumarto et al. (2017) stated that a work environment is a place where all employees can carry out activities, where they can have a positive or negative impact on employees to achieve their stated goals. A conducive work environment will stimulate the work spirit of the employees and will improve the performance and discipline in any job (Prakoso et al., 2014). A working condition covers a physical and non-physical environment which can lead to a fun, safe, and peaceful impression. An excellent working condition can stimulate a sense of satisfaction which may provide a positive influence on employee performance while the bad working condition will not cause employee satisfaction. A comfortable work environment will let the employees work harder and more concentrated on finishing their duties on time. Also, good working conditions will help reduce boredom and fatigue, so the performance of employees can improve (Wijaya \& Susanti, 2017).

Discipline is one of the factors that can enhance the performance of the employees. According to Hasibuan (2007), work discipline is the awareness and willingness of an employee to comply with all of the company rules and social norms. Work discipline is a tool used by managers to communicate with employees to change behaviour and to increase the awareness and willingness to meet all of the regulations of the company (Sulila, 2019).

Previous studies concerning the work environment on employee performance have been carried out by Budianto \& Katini (2015) who find out that the work environment can provide a positive and significant influence on employee performance. Besides, Alzghoul et al. (2018) explain that there is a significant influence of the physical work environment on employee performance. Moulana, Sunuharyo, \& Utami (2017) and Saputro \& Fathoni (2017) stated that the physical condition of the environment has a positive and significant effect on performance. On the other hand, Jerry, Tjia, \& Naga (2012) state that a direct relationship between the work environment and employee performance is not found.

The previous researches regarding the influence of work discipline on the work environment are those conducted by Inbar et al. (2018); Oktaria \& Nugraheni (2017); Herawati \& Ranteallo (2019) which indicate that work environment variables have a significant effect on the variable of work discipline of employees. Permadi (2017) and Putri et al. (2019) found that the work environment and work discipline can influence employee performance. Arsyad (2014) argues that work discipline has a significant positive effect on employee performance. Also, the study of Kuncorowati (2018) states that work discipline has a strong influence on performance. The inconsistency of study results from Permadi (2017) showed a positive and significant relationship, but Jerry, Tjia, \& Naga (2012) found no relationship between work environment and performance. Therefore, the different job satisfaction, commitment, work discipline, and subordinate perceptions might result in different employee performance. Based on these theories, this study aims to examine the influence of the work environment on employee performance mediated by work discipline. 


\section{Work Environment}

According to Sunyoto (2013), the work environment is everything around workers that can stimulate them to pursue and finish the tasks assigned, for example, housekeeping, music, lighting, and others. The work environment can determine the mood of employees upon working. The measurement indicator of the work environment, according to Sedarmayanti (2009) are: (1) physical work environment, i.e., all of the physical and visible things around the workplace that can directly or indirectly affect the work performance of the employees. The work environment is divided into two categories, the environment which is directly related to the employees and the intermediaries, or the global environment which can also refer to the work environment that affect the human condition; (2) non-physical work environment which is all the circumstance related to the employee relations, with either the managers, colleagues, or subordinates (Ekowati et al., 2020).

\section{Work Discipline}

According to Hasibuan (2007), work discipline is the awareness and willingness of an employee to comply with all of the company rules and social norms. Meanwhile, Mangkunegara (2006) argues that it may refer to the implementation of the management to strengthen the organizational guidelines. The indicators of work discipline, according to Guntur (1996) are the discipline of time, discipline on the target, discipline to quality, discipline to the job priority, and the discipline to the procedure.

\section{Performance}

Work performance is the work process and the result of an employee to achieve the expected goal (Wahyuni et al., 2014). According to Mangkunegara (2006), performance is the result of work in quality and quantity by an employee upon doing their duties and responsibilities given. Supriyanto et al. (2020) added that performance is a real behaviour shown in each employee's work performance based on their role in the company, where employees are critical in company's efforts to achieve its goals.

Kuswandi (2004) mentions some factors that affect the performance of employees: employee satisfaction, employee capabilities, leadership, motivation, and working environment. The working environment, both physical and non-physical ones make a significant contribution to improving the job satisfaction of employees (Nadia \& Fathurahman, 2017). A comfortable working environment for employees can improve performance. On the contrary, an inadequate work environment can degrade the performance, and thus it also lower the employee motivation. The indicators that affect employee performance are the quantity (the number of which must be completed), the quality (the number of products/ jobs produced), and the discipline of time (job's timeline) (Dharma, 1991).

\section{The Influence of Work Environment on Employee Performance}

The work environment refers to cleanliness, infrastructure, and comfort (Asmui et al., 2012). Every company or organization should keep the working environment and meet the standards of the work environment. It is an important factor due to its close relation to the daily activities of the employees at work. The employees who work in an uncomfortable environment will never work optimally, and they might be dissatisfied (Herawati \& Ranteallo, 
Supriyanto, A. S., Ekowati, V. M., \& Vironika, H.

Linking work environment to employee performance: the mediating role of work discipline

2019). Sedarmayanti (2009) reveals that to improve employee performance, a company must create a comfortable work environment. Besides, the study of Budianto \& Kantini (2015) shows that the work environment can provide a positive and significant influence on employee performance. Liyas \& Reza (2017) and Tjibrana, Bode, \& Lucky (2017) argue that the work environment can improve the performance of employees. Therefore, this research goes to the following hypotheses.

H1: Work environment directly impact on employee performance.

\section{Work Discipline Mediates the Relation of Work Environment with Employee Performance}

Hasibuan (2007) mentions that discipline is the essential operative function of human resource management because the more discipline the employee is, the higher the performance is achieved. The absence of discipline may hinder the organization from achieving optimal results. Permadi (2017) finds that the work environment significantly influences the performance of employees; the work environment affects the work discipline, and thus the work discipline has a significant effect on employee performance. Therefore mentioned argument goes to the following research hypothesis.

$\mathrm{H} 2$ : The discipline of work mediates the influence of work environment on employee performance.

\section{METHODS}

This research uses the explanatory approach to explain the causal relationship among variables through hypotheses testing. Therefore, the causative relation between two or more variables can be properly drawn. Data were obtained from a total of 78 employees of PT. Tinned Fish And Salted Seafood. The populations of this research are all of the employees of PT. Tinned Fish and Salted Seafood with 78 respondents as saturated samples. Data were analyzed with path analysis. In this study, testing mediation hypothesis is conducted by a procedure developed by Sobel Test, which is used to influence the work environment on employee performance through work discipline. The mediation of the examination employs the procedure developed by Sobel with software Free Statistic Calculation for Sobel version 4.0 .

In this study, the independent variable is the work environment. The indicator of the work environment refers to Sedarmayanti (2009), which is the physical and non-physical work environment. Meanwhile, the dependent variable is employee performance, which goes to quantity, quality, and punctuality (Dharma, 1991). The mediating variable is the work discipline, which comprises the discipline of time, regulations, and responsibility (Guntur, 1996).

\section{RESULT AND DISCUSSION}

\section{The Description of the Respondents' Characteristics}

The characteristics of the respondents of this study include age, gender, education, and working period. Among 78 respondents, the results of the analysis of the characteristics of respondents can be seen in Table 1. Table 1 shows that the characteristics of the respondents by gender show that $77 \%$ respondent is male and $18 \%$ is female. The respondent characteristics 
by education show that $52 \%$ respondent earn an undergraduate degree, $35 \%$ earn a senior high school degree, while the remaining respondents have a diploma and master degree. Meanwhile, based on the working period, most of the respondent (85\%) has less than five years of working experience, while $16 \%$ of them has worked about 5-10 years.

Table 1. Respondents' Characteristics

\begin{tabular}{lcc}
\hline \multicolumn{1}{c}{ Characteristics } & Number & Percentage \\
\hline Sex & 60 & \\
Male & 18 & $77.0 \%$ \\
Female & 78 & $24.0 \%$ \\
Number & & 100 \\
Education & 27 & $35.0 \%$ \\
Senior High School & 7 & $9.0 \%$ \\
Diploma & 41 & $52.0 \%$ \\
Undergraduate Degree & 3 & $4.0 \%$ \\
Master & 78 & 100 \\
Number & & \\
Duration & 66 & 85.0 \\
<5 years & 12 & 15.0 \\
5-10 years & 78 & 100 \\
Number & & \\
\hline
\end{tabular}

The test instrument validity is conducted to 78 respondents. A validity test is performed by finding out the correlation between the score of the statement and the total score variable. The validity test is valid if the coefficients are $\geq 0.3$, with $\alpha=0.05$ (Supriyanto \& Maharani, 2013). The result of the validity test shows that the items used to measure the variables of the work environment $(\mathrm{X})$ has high reliability with a Cronbach's Alpha value of 0.666. Besides, the validity test towards the employee performance variable (Y) has high reliability with a Cronbach's Alpha of 0.875 and work discipline variables with 0.773 . Therefore, Cronbach's Alpha of all variables is over 0.6 , which proves that all of the variables are reliable.

The normality test is used to acknowledge whether the residuals of the regression models examined are normally distributed. The method used to test normality is the KolmogorovSmirnov test. If the significance of the Kolmogorov-Smirnov test results is $\geq 0.05$, the normality assumption is met. The value of the Kolmogorov-Simornov $\mathrm{Z}=1.175$ with a significance level of 0.126 proves the normal distribution of the data because the significance level is $\geq 0.05$.

The linearity test is carried out to determine whether the model to be used in the study is linear or not. The results of the linearity test show that all of the work environments have a linear relationship with the performance of the employees, the work environment has a linear relationship with work discipline, and work discipline has a linear relationship with employee performance.

Table 2. The Goodness-of-fit Test

\begin{tabular}{lc}
\hline \multicolumn{1}{c}{ Relationship } & R Square \\
\hline Work environment $\rightarrow$ work discipline & 0.249 \\
Work environment, work discipline $\rightarrow$ employee performance & 0.364 \\
\hline
\end{tabular}

The goodness-of-fit test of the structural model used the predictive relevance (Q2) score to measure how observation scores are generated. Q2 was based on the coefficient of determination of 
Supriyanto, A. S., Ekowati, V. M., \& Vironika, H.

Linking work environment to employee performance: the mediating role of work discipline

all the dependent variables between $0<\mathrm{Q} 2<1$. $\mathrm{Z}$ variable has $\mathrm{R}^{2}$ of 0.249 . $\mathrm{Y} 1$ variable has $\mathrm{R}^{2}$ of 0.364 .

Predictive-relevance value is obtained by the formulation (1).

$\mathrm{Q}^{2}=1-\left(1-\mathrm{R}_{1}^{2}\right)\left(1-\mathrm{R}_{2}^{2}\right) \ldots\left(1-\mathrm{R}_{\mathrm{p}}^{2}\right)$

$\mathrm{Q}^{2}=1-(1-0.249) \times(1-0.364)$

$\mathrm{Q}^{2}=1-0.479$

$\mathrm{Q}^{2}=0.521$

The analysis showed that $\mathrm{Q}^{2}$ was 0.521 or 52.1 per cent, which showed that the model was able to explain 52.1 per cent of the data, while the remaining 47.9 per cent was explained by other variables (outside the model) and error.

\section{Hypothesis Testing}

The hypothesis testing is conducted by using a comparison of the t-statistics with the $\mathrm{t}$ table value. The value of the t-statistics is higher than the t-table value (1.960) which indicates a significant effect. The results of hypothesis testing are provided in Table 3.

Table 3. Hypothesis Testing

\begin{tabular}{cccccc}
\hline Hypothesis & Relationship & Coefficient & t-statistics & Significance & Description \\
\hline 1 & $\begin{array}{c}\text { Work environment } \rightarrow \\
\text { work discipline } \\
\text { Work environment, work } \\
\text { discipline } \rightarrow \text { employee } \\
\text { performance }\end{array}$ & 0.378 & 3.794 & 0.000 & Significant \\
2 & 0.348 & 3.490 & 0.000 & Significant \\
\hline
\end{tabular}

The results in table 3 show that the t-statistics is 3.794, which is higher than that of the $t$ table, which is 1.960 . Therefore, it proves that the work environment affects employee performance. The result explains that the value of t-statistics is 3.490, which is higher than the value of t-table 1.960. So, it proves that the work discipline mediates the variable of the work environment on employee performance variables.

\section{Path Analysis}

The current research is analyzed by using Path Analysis. This model is used to analyze the pattern of relationships among variables to determine the direct or indirect influence of a set of independent variables (exogenous) to the dependent variable (endogenous). The development of the pathway diagram is explained in Figure $1 \&$ Figure 2.

\section{Mediation Testing}

In this study, the hypothesis testing of mediation can be done with a procedure developed by Sobel known for the Sobel test with free statistical calculation software for the Sobel Test version 4.0. It is necessary to test the t-value of the coefficient ab to examine the significance of the indirect effect. The t-value is compared with the t-table value. Suppose the $t$-value $>t-$ table value, the influence of the mediation is detected. The result of the Sobel Test is $2.864 \geq 1.960$. Thus, the work discipline mediates the influence of work environment on employee performance.

Furthermore, to determine the nature of the relationship between variables either as a complete mediation, partial mediation or not as a mediating variable, the examination method is used (Hwang, Takane, Jung, 2017). To test for mediation, one should estimate the three 
following regression equations: regressing the dependent variable on the independent variable and regressing the dependent variable on both the independent variable and the mediator (Baron \& Kenny, 1986). If c and d are significant, and a not significant, it means a complete mediation occurs. If $\mathrm{c}$ and $\mathrm{d}$ are significant, and a significant, where the coefficient of $\mathrm{a}$ is smaller than coefficient $b$ then it is said to be a partial mediation variable. If $\mathrm{c}$ and $\mathrm{d}$ or both are not significant, then it is said not to be a mediating variable (Hwang, Takane, \& Jung, 2017). From the calculation results described in Figure 1 and Figure 2, it is known that the coefficient $a=0.378$ is smaller than the coefficient $b=0.386$. It means that the work discipline has partial mediation in the relationship between the work environment and employee performance.

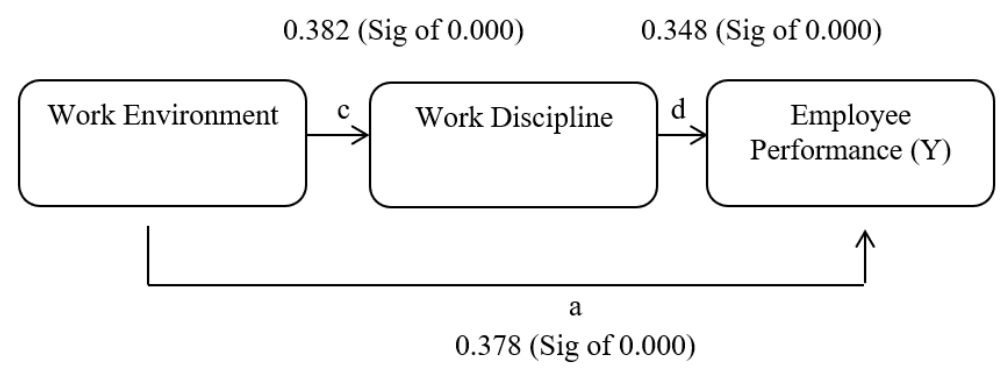

Figure 1. The Development of Pathway Diagram with Mediation Variable

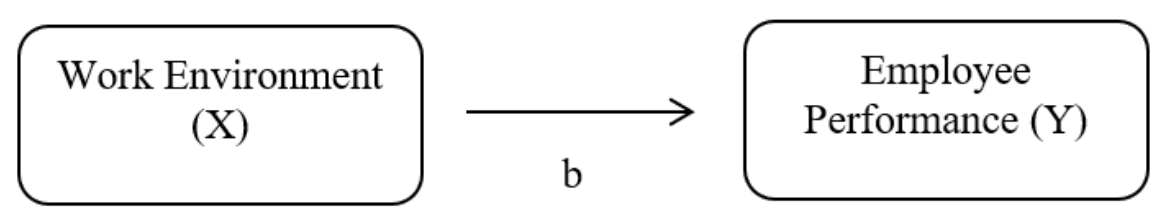

\subsection{6 (Sig of 0.000$)$}

Figure 2. The Development of Pathway Diagram without Mediation Variable

\section{Discussion}

The current research shows that the work environment has a significant influence on employee performance. It means that work environment variables give an impact on employee performance. It is because of the better the work environment, the better the employee performance. On the contrary, an uncomfortable environment may lead to ineffective and inefficient performance. This result is in line with the research conducted by Budianto \& Kantini (2015), Moulana, Sunuharyo \& Utami (2017), and Sari \& Aziz (2019) that the work environment affects employee performance. The conditions in the workplace are not in line with the research of Jerry, Tjia, \& Naga (2012) that the work environment does not influence the performance of employees.

The finding agrees with Alzghoul et al. (2018), Liyas \& Reza (2017), and Saputro \& Fathoni (2017) that the work environment can improve the performance of employees. Work environment, according to Pawirosumarto et al. (2017), was the place where all employees can carry out activities, where they can have a positive or negative impact on employees to achieve their stated goals. Those with positive work situations will show high motivation and vice versa. The intended work situation includes work relationships, work facilities, work climate, leader policies, work leadership patterns, and working conditions. Sedarmayanti (2009) reveals 
Supriyanto, A. S., Ekowati, V. M., \& Vironika, H.

Linking work environment to employee performance: the mediating role of work discipline

that both physical and non-physical work environments will affect the performance of the employees. The management of the company needs to balance them. Therefore, a supportive work environment is necessary to support the performance of employees in carrying out their work, so that the work can optimally be achieved.

The result of the research proves that the work discipline mediates the influence of work environment on employee performance. The finding is in line with the research conducted by Kuncorowati (2018) that work discipline has a significant influence on employee performance. This is also supported by Inbar et al. (2018) and Oktaria \& Nugraheni (2017) that work environment variables affect the work discipline of employees. Moreover, Permadi (2017) states that the work environment and work discipline influence on employee performance. Putri et al. (2019) also reveal that the work discipline mediates the effect of the work environment on employee performance.

The work environment has a direct influence on employee discipline upon completing responsibilities given by the company. Thus, companies need to give adequate attention to the work environment. A supportive work environment can provide a feeling of being secure at work. When the employees love the work environment, they will feel comfortable and can perform better activities, such as coming on time, completing better and faster tasks, and so forth. Thus, the work environment supports the completion of the tasks or the responsibilities of the employees within a company they work (Herawati \& Ranteallo, 2019).

The company's attention to discipline is expected to increase the performance of the employees. Besides, it needs to be supported by a good working environment for smoothness, security, safety, cleanliness, and comfort. Adequate facilities provided may lead to them to be safe, calm, and happy during working. Work discipline should always be maintained even improved. A disciplined employee is expected to put a maximum effort to finish the job so that it can produce optimal performance for the company. The employee will tend to be on time and obedient towards the company procedure, and highly responsible for any given jobs. A good discipline reflects a great sense of responsibility. It can stimulate the improvement of performance (Pangarso \& Susanti, 2016).

\section{CONCLUSION}

The result of the path analysis shows that the variables of work environment affect employee performance variables. This study accommodates some previous researches, that work environment can improve the performance of employees. The research finding concludes that PT. Tinned Fish and Salted Seafood working environment are convenient because employees always maintain their cleanliness. Besides, they can interact with both managers and colleagues.

This study combines the research that the work environment can increase employee performance when it is supported by work discipline. This study finds a close relationship between the variable of the work environment on employee performance mediated by work discipline. A comfortable work environment can create a discipline of the employees. Moreover, disciplined employees are more productive compared to those who are not.

The research results suggest several factors capable of increasing employee performance, such as work environment and work discipline. A leader needs to improve their work discipline in daily activities. The application of work discipline needs to be supported by 
both leaders and employees using the right policies. This study is limited to the use of a crosssectional survey. Therefore, it is highly recommended that further research employs a longitudinal survey for further verification upon the research variables used. Future studies need to carried out on the job satisfaction variable as a mediation. Future research should prioritize to use different moderation variables to enrich the scope of the study.

\section{REFERENCES}

Alzghoul, A., Elrehail, H., Emeagwali, O., \& Aishboul, M. (2018). Knowledge Management, Workplace Climate, Creativity, And Performance: The Role Of Authentic Leadership. Journal of Workplace Learning, 30(8), 592-612. https://doi.org/10.1108/JWL-12-20170111.

Arsyad, M. (2014). The Importance of Working Discipline to Improve Employee's Working Productivity of Motor Vassel Manufacturing Company in Makassar Shipyard. Business Management and Strategy, 5(2), 2157-6068. http://doi.org/10.5296/bms.v5i2.7194.

Asmui, M., Hussin, A. \& Paino, H. (2012). The Importance of Work Environment Facilities. International Journal of Learning \& Development, 2(1), 289-298, http://doi.org.10.5296/ijld.v2i1.1325.

Baron, R. M. \& Kenny, D. A. (1986). The Moderator-Mediator Variable Distinction in Social Psychological Research: Conceptual, Strategic, and Statistical Considerations. Journal of Personality and Social Psychology, 51(6), 1173-1182. https://doi.org/10.1037/00223514.51.6.1173.

Budianto, A. A. T. \& Katini, A. (2015). Pengaruh Lingkungan Kerja Terhadap Kinerja Pegawai Pada PT Perusahaan Gas Negara (Persero) Tbk SBU Distribusi Wilayah Jakarta. Jurnal Ilmiah Prodi Manajemen Universitas Pamulang, 3(1). http://dx.doi.org/10.32493/jk.v3i1.y2015.p\%25p.

Dharma, A. (1991). Manajemen Prestasi Kerja. Jakarta: PT. Rajawali.

Ekowati, V. M., Supriyanto, A. S., \& Aldi, S. (2020). Predicting Modelling of Factors Influencing Innovative Work Behavior. Technium Social Sciences Journal, 10(2020), 465-477. https://doi.org/10.47577/tssj.v10i1.1349.

Ghozali, I. (2013). Aplikasi Analisis Multivariate dengan Program IBM SPSS 21.Universitas Diponegoro. Semarang.

Guntur. (1996). Jaminan Sosial Tenaga Kerja. Jakarta: Airlangga.

Hasibuan, M. (2007). Organisasi dan Motivasi Cetakan Kesepuluh. Jakarta: Bumi Aksara.

Herawati, N. \& Ranteallo, A. T. (2019). Analisis Pengaruh Lingkungan Kerja terhadap Disiplin Kerja Karyawan. Jurnal AKRAB JUARA, 4(2), 27-41.

Inbar, N. R. D., Astuti, E. S., \& Sulistyo, M. C. W. (2018). Pengaruh Lingkungan Kerja terhadap Disiplin Kerja dan Semangat Kerja Karyawan (Studi Pada Karyawan PDAM Kota Malang). Jurnal Administrasi Bisnis, 58(2). 
Supriyanto, A. S., Ekowati, V. M., \& Vironika, H.

Linking work environment to employee performance: the mediating role of work discipline

Jerry, M. L., Tjia F. T., \& Naga, N. (2012). Analisis Pengaruh Lingkungan Kerja dan Pemberian Kompensasi terhadap Kinerja Karyawan CV Mum Indonesia. Binus Business Review, 3(1), 573-586. https://doi.org/10.21512/bbr.v3i1.1344.

Kuncorowati, H. (2018). The Influence of Communication and Work Discipline on the Employee Performance (A Case Study of Employee Performance of Dwi Arsa. Journal of Arts, Science \& Commerce, 9, 2229-4686. https://doi.org/10.18843/rwjasc/v9i2/02.

Kuswandi, W. (2004). Komunikasi Massa. Penerbit PT. Jakarta: Rineka Cipta.

Liyas, N. R. \& Reza, P. (2017). Pengaruh Disiplin Kerja terhadap Kinerja Karyawan pada Bank Perkreditan Rakyat. Jurnal Lembaga Keuangan dan perbankan, 2(1), 17-26. http://dx.doi.org/10.15548/al-masraf.v2i1.88.

Mangkunegara, A.P. (2006). Evaluasi Kinerja SDM. Bandung: PT Refika Aditama.

Martono, N. (2010). Metode Penelitian Kuantitatif. Jakarta: PT. Raja Grafindo Persada.

Moulana, F., Sunuharyo, B., \& Utami, H. (2017). Pengaruh Lingkungan Kerja terhadap Kinerja Karyawan melalui Variabel Mediator Motivasi Kerja (Studi pada Karyawan PT. Telkom Indonesia,Tbk Witel Jatim Selatan, Jalan A. Yani, Malang). Jurnal Administrasi Bisnis, 44(1), 178-185.

Nadia, Fathurahman, H. (2017). Relationships between Physical Working Environment, Employee Well-being, and Employee Commitment in Hospital Management. International Journal of Administrative Science \& Organization, 24(3), 140-144.

Oktaria, R. A. \& Nugraheni, R. (2017). Pengaruh Lingkungan Kerja, Kepuasan Kompensasi, Dan Motivasi Kerja terhadap Disiplin Kerja Pegawai Pada Pdam Tirta Moedal Kota Semarang. Diponegoro Journal of Management, 6(3), 439-448.

Pangarso, A. \& Susanti, P. I. (2016). Pengaruh Disiplin Kerja t terhadap Kinerja Pegawai Dibiro Pelayanan Sosial Dasar Sekretariat Daerah Provinsi Jawa Barat. Jurnal $\begin{array}{llll}\text { Manajemen Teori dan Terapan, } & \text { 9(2), }\end{array}$ http://dx.doi.org/10.20473/jmtt.v9i2.3019.

Pawirosumarto, S., Sarjana, P. K., \& Gunawan, R. (2017). The Effect of Work Environment, Leadership Style, and Organizational Culture Towards Job Satisfaction and its Implication Towards Employee Performance in Parador Hotels and Resorts, Indonesia. International Journal of Law and Management, 59(6), 1337-1358. https://doi.org/10.1108/IJLMA-10-2016-0085.

Permadi, I. (2017). Pengaruh Lingkungan Kerja dan Disiplin Kerja terhadap Kinerja Karyawan Pada CV Alam Hijau Sukabumi. Jurnal Ekonomak, 3(1).

Prakoso, R. D., Astuti, E. S., \& Ruhana, I. (2014). Pengaruh Lingkungan Kerja terhadap Motivasi Kerja dan Kinerja Karyawan (Studi Pada Karyawan PT. AXA Financial Indonesia Cabang Malang). Jurnal Administrasi Bisnis (JAB), 14(2), 1-10.

Putri, E. M., Ekowati, V. M, Supriyanto, A. S., \& Mukkafi, Z. (2019). The Effect of Work Environment on Employee Performance through Work Discipline. International Journal 


$$
\begin{aligned}
& \begin{array}{llllll}
\text { of } \quad \text { Research } & - & \text { GRANTHAALAYAH, } & 7 & \text { (4), } & \text { 132-140. }
\end{array} \\
& \text { https://doi.org/10.5281/Zenodo.2653144. }
\end{aligned}
$$

Sani, A. \& Maharani, E. V. (2019). Spirituality at Work and Organizational Commitment as Moderating Variables in Relationship between Islamic Spirituality and OCB IP and Influence Toward Employee Performance. Journal of Islamic Marketing. 11(6), 17771799. https://doi.org/10.1108/JIMA-08-2018-0140.

Saputro, G. \& Fathoni, A., F. (2017). Analisis Pengaruh (Human Relation/ Hubungan Antar Manusia) dan Kondisi Fisik Lingkungan Kerja terhadap Etos Kerja dan Kinerja Karyawan PT Karunia Adijaya Mandiri Semarang. Journal of Management, 3(3), 9. http://jurnal.unpand.ac.id/index.php/MS/article/view/730711.

Sedarmayanti. (2009). Sumber Daya Manusia dan Produktivitas Kerja. Bandung: CV Mandar Maju.

Sekaran, U. (2003). Research Methods For Business A Skill-Building Approach. New York: John Wiley and Sons.

Sobel, M. E. (1982). Asymptotic Confidence Intervals for Indirect Effects in Structural Equations Models. In S. Leinhart (Ed.), Sociological methodology (pp. 290-312). San Francisco, USA: Jossey-Bass.

Hwang, H., Takane, Y., \& Jung, K. (2017). Generalized structured component analysis with uniqueness terms for accommodating measurement error. Frontiers in psychology, 8, 2137.

Sulila, I. (2019). The Effect of Discipline and Work Motivation on Employee Performance, BTPN Gorontalo. International Journal of Applied Business \& International Management, 4(3), 121-131. https://doi.org/10.32535/ijabim.v4i3.690.

Sunyoto, D. (2013). Teori, Kuisioner, dan Analisis Data Sumber Daya Manusia (Praktik Penelitian). Yogyakarta: CAPS (Center of Academic Publishing Service).

Supriyanto, A. S. \& Maharani, V. (2013). Metodologi Penelitian Manajemen Sumberdaya Manusia Teori Kuisioner dan Analisis Data. Malang: UIN-Maliki Press.

Supriyanto, A. S. \& Ekowati, V. M. (2019). Riset Manajemen SDM, untuk Skripsi, Tesis, dan Disertasi, dan Dilengkapi dengan Contoh Artikel Jurnal. Malang: Inteligensia Media.

Supriyanto, A. S., Ekowati, V. M., \& Maghfuroh, U. (2020). Do Organizational Citizenship Behaviour and Work Satisfaction Mediates the Relationship between Spiritual Leadership and Employee Performance?. Management Science Letters, 10(5), 11071114. https://doi.org/10.5267/j.msl.2019.10.031.

Timpe, D. (2002). Leadership, Seri Manajemen Sumberdaya Manusia. Jakarta: PT Elex Media Komputindo.

Tjiabrana, F. R., Bode, L., \& Lucky, O. H. D. (2017). Pengaruh Beban Kerja \& Lingkungan Kerja terhadap Kinerja Karyawan PT. Sabar Garda Manado. Jurnal Riset Ekonomi, 
Supriyanto, A. S., Ekowati, V. M., \& Vironika, H. Linking work environment to employee performance: the mediating role of work discipline Manajemen, Bisnis dan Akuntansi, $5 \quad$ (2), 1570-1580. https://doi.org/10.35794/emba.v5i2.16227.

Wahyuni, D., Utami, H. A., \& Ruhana, I. (2014). Pengaruh Pengembangan Karier terhadap Prestasi Kerja Karyawan. Jurnal Administrasi Bisnis (JAB), 8 (1), 1-10.

Wijaya, H., \& Susanty, E. (2017). Pengaruh Lingkungan Kerja terhadap Kinerja Pegawai pada Instansi Pemerintah Daerah Kabupaten Musi Banyuasin (Studi Kasus Dinas Pertambangan dan Energi Kabupaten Musi Banyuasin) Jurnalecoment Global, 2(1), 4050. http://dx.doi.org/10.35908/jeg.v2i1.213. 